Dr BOŠKO MIJATOVIĆ,viši naučni saradnik

Centar za liberalno-demokratske studije

Beograd, Kralja Milana 7

UDK 336.743(497.1)"1919/1921"

336.748.5(497.1)"1918/1921"

\title{
ZAMENA AUSTRIJSKIH KRUNA ZA DINARE 1920. GODINE ${ }^{1}$
}

\begin{abstract}
APSTRAKT: Po formiranju Kraljevine SHS trebalo je povući iz opticaja više valuta radi ostvarenja monetarne suverenosti i stabilnosti. Pitanje je bilo politički osetljivo pošto se zamenom novca raspodeljuje kupovna snaga na pokrajine i narode. U februaru 1920. pristupilo se zameni kruna. Primenjeni kurs iznosio je 4 krune za 1 srpski dinar, što je bilo razumno polazeći od veće kupovne snage dinara u odnosu na krunu, berzanskog kursa, daleko veće podloge dinara nego krune i potrebe kompenzacije dinarskog područja za eksprorijativni kurs koji su austrougarske vlasti primenjivale tokom rata. Posledice zamene bile su povoljne. Vlasnici kruna u Jugoslaviji prošli su znatno bolje nego vlasnici u Austriji i Mađarskoj. U zemlji je vladala odlična poslovna konjunktura. Kurs novog dinara je znatno porastao po unifikaciji, a zamena nije donela priliv malovrednih kruna iz okruženja, pa je tako sačuvan kapital Jugoslavije.
\end{abstract}

Ključne reči: kruna, dinar, zamena novca, kurs, Austro-Ugarska, Jugoslavija

Unifikacija novca u novostvorenoj Kraljevini SHS godine ne bi bila važna epizoda iz ekonomske istorije da tokom sledećih decenija nije često korišćena u političke svrhe, uglavnom na pamfletski način. Stoga je njeno preispitivanje i danas zanimljiv poduhvat, čak potreban radi uklanjanja netačnosti koje su se skupile tokom vremena.

\section{Uvod}

Po ujedinjenju 1. decembra 1918, vladu je čekalo više važnih poslova, kao što su izgradnja osnovnih državnih institucija, od donošenja ustava i

${ }^{1}$ Zahvaljujem se Borisu Begoviću, Ljubomiru Madžaru i Branku Milanoviću na korisnim sugestijama. 
parlamentarnih izbora nadalje; tekuće finansiranje budžeta nove države, a bez jedinstvenog poreskog sistema i administracije; valutno pitanje, pošto je zemljom cirkulisalo više valuta; ekonomsko povezivanje zemlje, posebno saobraćajno; i obnova Srbije, koja je veoma teško stradala u Prvom svetskom ratu.

Konstituisanje države nije brzo izvedeno, usled velikih razlika $\mathrm{u}$ pogledima na državno uređenje. Ustav je usvojen tek sredinom 1921, pa je nepostojanje ustava i na njemu zasnovanih osnovnih zakona dovelo do upravljanja državom na osnovu privremenih propisa. Zadržano je finansiranje po istorijskim pokrajinama. Deficit državnog budžeta za 1919-1920. dostigao je 1,8 milijardi, a finansiran je, između ostalog, iz 20\% zadržanih kruna prilikom markiranja u iznosu od 922 miliona kruna i sa 300 miliona kruna uzetih radi zamene pohabanih novčanica, a koje nisu zamenjene (videti kasnije). ${ }^{2}$ Nova država je, zbog slabe naplate dažbina, odmah zapala u finansijsku krizu, što će se nastaviti i tokom sledećih godina. Važan oslonac budžeta do 1922. godine bila je Narodna banka, što se odražavalo i na valutne odnose.

\section{VALUTNO PITANJE}

Na teritoriji zemlje je krajem 1918. cirkulisalo više valuta: austrougarska kruna, srpski dinar, crnogorski perper, nemačka marka i bugarski lev. Valutni problem sastojao se u pitanju kako izvesti unifikaciju valuta na najefikasniji i najpravedniji način kako bi se postavili temelji novčane stabilnosti. Zamena leva i perpera nije donela većih teškoća.

Zamena kruna za dinare bila je važno i finansijsko i političko pitanje. Njegova osetljivost, ali i potencijal za pravljenje političkih teškoća proističe iz činjenice da se radi o jednom redistributivnom pitanju: kako, kroz razmenski odnos krune i dinara, raspodeliti postojeću kupovnu snagu u novoj državi? Kome koliko? Budući da je bilo verovatno da će i srpski dinar i kruna biti zamenjen novim, jugoslovenskim dinarom, problem se sveo na pitanje njihovih kurseva prema tom novom dinaru, što znači i međusobno. Ukoliko uslovi zamene, a prvenstveno kurs, budu previše povoljni po krunu, krunsko područje (prečanski krajevi) dobiće više nego što treba, možda uz izvesnu inflaciju, a ukoliko budu nepovoljni, ovo područje će biti oštećeno, možda uz pad ekonomske aktivnosti. Za dinarsko područje važi suprotno. Pored ekonomskog, svakako postoji i politički aspekt, od sukoba regionalnih i nacionalnih interesa preko truda stranaka da poboljšaju sopstveni rejting i pridobiju narod za sopstvenu političku orijentaciju do lobiranja poslovnih krugova u korist sopstvenog profita.

\footnotetext{
${ }^{2}$ S. Šećerov, Naše finansije 1918-1925, Beograd 1926, 14.
} 
U osnovi, valutno pitanje se sastojalo od tri potpitanja: (1) ko će biti izdavalac novog novca - država ili emisiona banka; (2) kakva će i kolika biti podloga tog novca; i (3) koliki će biti kurs zamene dveju postojećih valuta prema novom novcu.

U tadašnjim vremenima u razvijenom i srednje razvijenom delu sveta dominirao je monetarni sistem zasnovan na plemenitim metalima, posebno na zlatu, kod koga je emisiona banka garantovala da se papirne novčanice mogu slobodno i u svakom trenutku zameniti za zlato na bančinim blagajnama. Jedino takav novac uživao je poverenje građana i onemogućavao državi inflacionu emisiju papirnog novca. Zlatni standard je obezbedio stabilnost novca i lep ekonomski napredak razvijenijeg dela sveta u nekoliko decenija pre Prvog svetskog rata, pa su sve zemlje žurile da mu se vrate po okončanju rata.

\section{Dinar za vreme rata}

U predvečerje Prvog svetskog rata Srbija je imala da obavi dva monetarna zadatka: prvo, da zameni turski novac srpskim u krajevima oslobođenim u Balkanskim ratovima, što bi trebalo da dovede do udvostručenja opticaja; i drugo, da finansira dodatne rashode za Balkanske ratove, što je učinjeno iz pozajmica u inostranstvu. To je dovelo do vidljivog povećanja novčanog opticaja, posle razmene državnog zlata inostranog porekla za dinare. Početkom 1914. godine novčana situacija je sređena, pa se ponovo za zlatne novčanice moglo neograničeno dobiti zlato. Štaviše, u proleće 1914. planirana je novčana reforma kojom je trebalo napustiti bimetalni (srebro, zlato) i preći na zlatni standard, s novčanicama koje bi isključivo glasile na zlato. ${ }^{3}$

Za godinu i po dana od početka rata do kraja 1915. godine, što je vreme u kome je Srbija uglavnom bila slobodna, novčani opticaj je povećan sa 103,2 miliona krajem 1913. na 297,8 miliona krajem 1915. godine, a znatnim delom za državne potrebe. Za vreme izbeglištva opticaj je praktično stagnirao (340,6 miliona krajem 1918), ${ }^{4}$ što je prirodno budući da je izgubljena državna teritorija. Deo novčanica ostao je u Srbiji, dok je drugi deo iznet od strane vlade, Narodne banke i vojske. Novac koji je ostao u zemlji delom je tezaurisan od strane stanovništva, a delom zamenjen krunom koju su nametnule okupacione vlasti, uz prinudni kurs od dva dinara za jednu krunu, počevši od masovnih rekvizicija nadalje. ${ }^{5}$ Taj kurs je bio $u$

${ }^{3}$ V. Bajkić, Predstojeća novčana i bankarska reforma u Srbiji, u: Srpski ekonomisti do 1914, zbornik, priređivač B. Mijatović, Beograd 2008, 308 i 309.

${ }^{4}$ Narodna banka 1884-1934, Beograd 1934, 287.

${ }^{5}$ M. Ninčić, Naše valutno pitanje, 30. novembar 1919, Beograd 1920, 63; Pravda, 1. februar 1919. 
neskladu s predratnim od 1,05 dinara za jednu krunu i kasnijim novčanim promenama. Naime, rast novčanog opticaja u Austro-Ugarskoj i krunska inflacija bili su brži nego dinarski, pa bi ekvivalentna razmena u 1916. godini trebalo da donese kurs po kome bi dinar bio jači od krune. Prinudnim kursom okupaciona vlast je eksproprisala imovinu u Srbiji i podstakla stanovništvo na tezauraciju dinara i čekanje oslobođenja.

Povećanje novčanog opticaja bilo je praćeno rastom podloge, jer je država, uz finansijsku podršku saveznika, svoja preuzimanja novčanica u prvom periodu pratila predajom metala Narodnoj banci. Potom je počela predavati i svoja potraživanja prema inostranstvu, a zatim i akreditive savezničkih vlada, što je donekle kvarilo kvalitet podloge, ali uz visoku pokrivenost novčanica: $87,3 \%$ u 1918. godini $\left(85,5 \%\right.$ u 1912). ${ }^{6}$

\section{Propadanje krune}

U Austro-Ugarskoj je rat uglavnom finansiran novčanom emisijom. Tehnički je to izvođeno tako što je država izdavala ratne obveznice, a njih kupovala centralna banka. Stoga je tokom ratnih godina došlo do vrlo brzog rasta novčanog opticaja i cena: tako je u novembru 1918. opticaj novca 13,2 puta veći, cene 16,4 puta više, a kurs u Cirihu 3 puta viši u odnosu na juli 1914. godine. ${ }^{7}$ Novčana podloga je $u$ istom periodu opala sa 1241 na 261 milion kruna krajem 1918, a veći deo se preselio u nemačku Rajhsbanku. ${ }^{8}$

Tokom oktobra i novembra 1918. stvaraju se nezavisne države Kraljevina SHS, Čehoslovačka, Poljska i Mađarska, gube se i druge teritorije, a carevina svodi na Austriju, koja ne uspeva da stabilizuje državne finansije, pa se nastavlja praksa inflatornog finansiranja. U ovom periodu kurs krune prema stabilnom dolaru brzo je opadao: od 17,09 za dolar u januaru 1919. do $271,43 \mathrm{u}$ januaru 1920. godine, ${ }^{9}$ što znači 15,9 puta više kruna za dolar posle samo godine dana.

Deficitno finansiranje budžeta tokom 1918. i 1919. donelo je inflaciono oporezivanje zemalja naslednica, budući da su korist od štampanja novog novca imale isključivo Austrija i Mađarska dok su troškovi obezvređenja novca pali na sve zemlje. Inflaciono oporezivanje ozbiljno je zabrinulo vlade izdvojenih zemalja krunskog važenja i ubrzo ih navelo na reakcije

\footnotetext{
${ }^{6}$ Narodna banka 1884-1934, 94-95.

${ }^{7}$ R. Dornbush, Post-Communist Monetary Problems, Lessons from the End of the Austro-Hungarian Empire, ICEGP, 1994, 9.

${ }^{8}$ J. P. Young, European Currency and Finance, Vol. 2, US Senate, 11-12.

${ }^{9}$ T. Sargent, The Ends of Four Big Inflations, u Robert E. Hall (ed), Inflation: Causes and Effects, Chicago, 1982, 52
} 
(žigosanje i markiranje kruna, ${ }^{10}$ izdavanje sopstvenog novca), koje su okončale monetarnu uniju, odnosno slobodnu cirkulaciju kruna na ovom prostoru. Nema sumnje i da je težnja za monetarnom suverenošću novih država igrala važnu ulogu.

Raspadanje starog monetarnog sistema dovodilo je do špekulativnog prelivanja kruna iz jedne zemlje u drugu, pri čemu su investitori, ali i građani pokušavali da predvide budućnost i na tome zarade ili da izgube što manje. Jedan motiv špekulacije bile su razlike u stopama konverzije, koje su, zajedno s različitim nivoima cena, dovodile do pokušaja njihovog profitnog iskorišćavanja kroz procese arbitraže ${ }^{11}$ i prateće tokove kruna. Drugi motiv je promena realne tražnje za novcem u različitim zemljama (u inflacijom zahvaćenoj ona opada, a u stabilnoj raste); stoga se uravnoteženje realne tražnje za novcem može postići transferom "stare" valute iz inflacione u stabilnu zemlju. ${ }^{12}$ Ovome se mogu dodati i razna administrativna ograničenja u raspolaganju novcem (zamrzavanje depozita, prinudni zajmovi), što je imaoce kruna činilo nezadovoljnim i stvaralo podsticaj za selidbu u povoljnije zemlje. ${ }^{13}$ Bilo je i slučajeva „denacionalizacije“ kroz skidanje žigova ili markica, kao u Jugoslaviji. Stoga su milijarde kruna tražile poslednju destinaciju, zavisno od ponuđenih uslova. Tako se procenjuje da je Austriju i Čehoslovačku napustilo 6,5 milijardi kruna prilikom žigosanja i zamene. Naime, u Austriji su se očekivali visoka taksa i zamrzavanje depozita, dok je u Čehoslovačkoj zadržano 50\% zamenjenih kruna. Na kraju je veliki krunski talas uglavnom našao konačnu destinaciju $u$ Rumuniji (usled povoljnog kursa pojavilo se četiri puta više kruna nego što je očekivano) i Mađarskoj, koja je poslednja vršila žigosanje od marta 1920. (sa zadržavanjem $50 \%$ vrednosti na ime prinudnog zajma) i tek od 1921. počela zamenu novčanica, s ukupnim iznosom od čak 20,7 milijardi kruna. $^{14}$

10 Žigosanje je obeležavanje svake novčanice pečatom nove vlasti, one koja nije izdala novčanicu. Markiranje je slično: lepljenje specijalne markice umesto pečata.

${ }^{11}$ Arbitraža je proces koji dovodi do ujednačavanje cena jedne robe na različitim tržištima (npr. berzama), a sastoji se od preusmeravanja ponude i tražnje sa jednih na druga tržišta.

${ }^{12}$ Detaljnije: P. Garber and M. Spencer, The Dissolution of The Austro-Hungarian Empire: Lessons for Currency Reform, Princeton, 1994, 7-8.

${ }^{13}$ J. P. Young, $n$. d., o situaciji u Austriji 1919. kaže: „Ali, mnogo je bančinih novčanica ostalo nežigosano kako bi se izbegle fiskalne mere ili zato što je smatrano da će novčanice biti vrednije sa pravim ili falsifikovanim žigom druge zemlje... Živahna trgovina... stvorila je privremeni haos u monetarnoj situaciji istočne Evrope“, str. 12; čak, povremeno su nežigosane krune imale višu tržišnu cenu od žigosanih, zbog šireg izbora opcija, prema P. Garber and M. Spencer, $n$. d., 14.

${ }^{14}$ P. Garber and M. Spencer, n. d., 17 i 19. 


\section{PRIPREME ZA ZAMENU KRUNSKIH NOVČANICA}

\section{Prve ideje}

Prilikom formiranja Kraljevine SHS postavilo se pitanje šta raditi sa austrijskim krunama u novoj državi. Pravno posmatrano, bilo je moguće proglasiti taj novac ništavnim, jer je pripadao drugoj državi, to jest Jugoslavija ga nije izdala niti za njega garantovala, pa čak nije za njega imala ni metalnu podlogu. I emotivni razlozi, makar u predratnoj Srbiji, govorili su za poništavanje, jer je to bio novac mrskog neprijatelja koji je doneo toliko smrti i razaranja. Slično je mislio i deo političara iz prečanskih krajeva (Nikola Vinterhalter, Vitomir Korać, Janko Šimrak, Ivan Ancel). ${ }^{15}$ Politički razlozi govorili su protivrečno: protiv krune bila je želja da se dinar ne kvari zarad problematičnog novca, a, nasuprot tome, stajao je razlog poštovanja privatne imovine, pošto bi poništavanje kruna uništilo novčani deo imovine građana sa krunskog područja; ${ }^{16}$ zatim, politički nije pametno započeti zajednički život likvidacijom novčanog dela imovine polovine građana države. Protiv poništavanja kruna govorio je i ekonomski razlog: ono bi radikalno smanjilo kupovnu moć znatnog dela stanovništva i najverovatnije donelo ekonomsku krizu, na štetu svih stanovnika i budžeta nove države.

Još pre 1. decembra 1918. započeta su razmatranja valutnog pitanja. Prvo je Milko Brezigar, ekonomski stručnjak i član Narodnog veća SHS, podneo ekspoze na sednici Privrednog odbora ljubljanskog Narodnog veća 21-22. oktobra 1918. Smatrao je neminovnim da buduća valuta bude dinar, a da, sa stručnog stanovišta, nije pravedno u celini isplatiti austrijski novac dinarima. Procenjivao je da na jugoslovenskom prostoru cirkuliše 4,25 milijardi kruna i da one, zbog najmanje šestostrukog povećanja cena, vrede samo jednu šestinu predratne vrednosti. Predložio je žigosanje kruna, s tim da bi njime trebalo obuhvatiti samo 15-20\% novčanica i tako ih pretvoriti u domaći novac, čime bi se smanjio preterani broj kruna i povećala njihova vrednost. ${ }^{17}$ Takođe, razumno je procenjivao da je „sasvim moguće da će doći do velikih komplikacija političkog značaja između pokrajina Države SHS i stare Srbije“. ${ }^{18}$ Početkom novembra Vekoslav Kukovec, poverenik za finansije slovenačke vlade, takođe je predlagao žigosanje kruna kako bi se sprečio dotok iz drugih zemalja. ${ }^{19}$

${ }^{15}$ Lj. Kosier, Narodna banka Kraljevine Srba, Hrvata i Slovenaca 1884-1924, Zagreb 1924, 239.

${ }^{16}$ V. Bajkić, Izabrani spisi, 103-104.

17 J. Šorn, Slovensko gospodarstvo v poprevratnih letih 1919-1924, Ljubljana 1997, 62.

${ }^{18} \mathrm{~J}$. Šorn, Narodni svet $v$ Ljubljani in njegov gospodarski odsek, Prispevki za zgodovino delavskega gibanja, br. 1-2/1983, 59.

${ }^{19}$ B. Balkovec, Prva slovenska vlada 1918-1921, Ljubljana 1992, 130. 
Zatim je Finansijski odbor Narodnog veća SHS iz Zagreba detaljno razmatrao ovo pitanje i našao da je, bez sumnje, potrebno zameniti („,iskupiti“) krune domaćim novcem. Verovali su da se od austrougarske garancije novca ništa ne može očekivati, ali su smatrali da je „u interesu“ novih država da preuzmu tu obavezu i ne likvidiraju imovinu svojih građana. Odbor se izjasnio i protiv brze zamene kruna novim novcem, već je savetovao da se pričeka obezbeđenje njegove podloge, a da se u međuvremenu koriste krune, zadrži kontinuitet sa Austrougarskom bankom (dalje: AU banka) i uzme kontrola nad njom kako ne bi više štampala novac bez pokrića. Odbor je zaključio i da je žigosanje kruna prihvatljivo jedino ukoliko je već doneta odluka o zameni kruna, a ne o njihovom poništavanju. ${ }^{20}$ Protiv žigosanja naveden je sledeći razlog: ono će podići vrednost krune i privući velike količine kruna iz okruženja. Finansijski odbor je januara 1919. poslao u Beograd delegaciju koju su činili direktori najvećih banaka i koju je primio i regent Aleksandar. ${ }^{21}$ Ideja o kontinuitetu može se razumeti kao izraz poslovnog interesa da se očuvaju stare ekonomsko-finansijske veze sa Austrijom i Mađarskom, ali svakako nije bila ni realistična, ni finansijski promišljena. Jer, krunska monetarna unija nije imala političke šanse, dok bi zadržavanje austrijske krune bez žigosanja donelo vlasnicima velike gubitke na kontinuelnom padu njene vrednosti.

Zaokružen koncept formulisao je mladi Ivo Belin pred kraj 1918. godine. Verovao je da je neminovno da dinar bude valuta nove države, kao i da je osnovno pitanje „u kojem će se razmjeru krune izmeniti s dinarima“. Jasno je video opasnost priliva kruna iz drugih delova bivše Monarhije: „Naglašujem, ako bi razmjer bi povoljan“, onda bi krune „nahrupile ovamo da budu zamijenjene za dinar". To bi trebalo sprečiti žigosanjem, a zatim brzom zamenom žigosanih kruna provizornim državnim dinarom po kursu 1:1. Na kraju bi provizorni novac trebalo zameniti za dinare Narodne banke. Bitno je da se kurs ove poslednje zamene ne saopštava unapred kako bi što manje novčanica došlo iz inostranstva. Potom bi se za stare krune, koje se sve nalaze u rukama države, moglo tražiti učešće u likvidacionoj masi AU banke. Na kraju je Belin, zagovornik zlatnog standarda i deflacije, zapitao kako povući višak novčanica iz opticaja, odnosno ko da snosi materijalne žrtve. „Naravno mi, bivši teritorij Austro-Ugarske moramo da snosimo te troškove, prvo jer su to i naši grijesi, a drugo, jer smo ekonomski jači nego tamo preko Drine, Save i Dunava". Za prikupljanje novca u te svrhe predložio je ratni porez na bogataše. ${ }^{22}$ Budući da su vladini planovi za zamenu

\footnotetext{
${ }^{20}$ Hrvatski Lloyd, 16. novembar 1918, preneto u Lj. Kosier, n. d., 225-229.

${ }^{21}$ Obzor, 10. januar 1919.

22 I. Belin, Problem valute, Jugoslavenska njiva, 25. januar 1919, 60.
} 
kruna bili dosta slični Belinovim idejama, možda je ovaj članak izvršio uticaj u Beogradu.

Ministar finansija Momčilo Ninčić je 25. decembra 1918. izneo svoju osnovnu orijentaciju u valutnim pitanjima. Izrazio je veliku zabrinutost zbog rizika koji donosi nekontrolisano štampanje kruna u Beču i Pešti i prelivanje $\mathrm{u}$ druge zemlje. Nije verovao $\mathrm{u}$ povoljne rezultate zabrane unosa kruna u zemlju, jer nije postojalo dovoljno čuvara za toliko dugu granicu. Određene nade polagao je u uticaj Antante na obustavljanje štampanja kruna, ali je osnovnu strategiju vezao za zamenu kruna domaćim državnim novcem, uz dogovor s pravnim sledbenicima AU banke o podeli podloge i drugim pitanjima. Tvrdeći da je stvar „hitna“, rekao je da će odmah potražiti zavod koji bi u kratkom roku mogao naštampati potrebne novčanice. Oko kursa zamene ocenio je da je postojeći kurs kruna - dinar koji primenjuje država od 2:1 već nerealan, a da bi „veštačko održavanje“ „zvaničnog“ (predratnog) kursa krune „dovuklo... milijarde novčanica u zemlju i izazvalo finansijsku katastrofu u državi“ ${ }^{23}$ Tih dana je formirao i komisiju (Milko Brezigar, Velizar Janković i Milan Marković) koja će obići Beč i Peštu radi monetarnih poslova i Prag radi narudžbine novčanica. ${ }^{24}$ Komisija nije uspela da dogovori obustavu emisije AU banke i navela je reči potpredsednika Grubera da je bolje nastaviti s njom nego „dati maha boljševizmu“. ${ }^{25}$

\section{Žigosanje kruna}

Neuspeh da se obuzda AU banka podstakao je Vladu da pređe na domaće mere, pa je već 12 . decembra, ni dve nedelje po osnivanju države, naredila žigosanje kruna „u cilju sprečavanja daljeg padanja vrednosti“ krune. Drugi razlog bio je statistički - da se ustanovi koliko je kruna u zemlji. Istovremeno je zabranjen uvoz više od 1.000 kruna i izvoz novca iz zemlje (ovo je trebalo da koliko-toliko spreči „poplavu naše novčane pijace papirnim novcem neprijateljskih država") i propisano je da nežigosane krune više nisu zakonsko sredstvo plaćanja. Treći razlog bila je namera da se „preseku planovi" o monetarnoj (i carinskoj) uniji na području Monarhije, koji su pravljeni i u zemlji i u inostranstvu. „Žigosanje kruna razbilo je fantazije o monetarnoj uniji" i očuvanju Monarhije u bilo kom obliku, rekao je Ninčić. ${ }^{26}$

Već početkom januara 1919. započeto je žigosanje krunskih novčanica domaćim pečatima, čime je izvršeno njihovo izdvajanje iz austrijskog monetarnog sistema. Zbog hitnosti akcije nije se išlo na štampanje novih

\footnotetext{
${ }^{23}$ Pravda, 13. decembar 1918 (po starom).

${ }^{24}$ Pravda, 14. decembar 1918 (po starom).

${ }^{25}$ M. Ninčić, Naše valutno pitanje, 9.

${ }^{26}$ Isto, 12.
} 
novčanica, iako se znalo da je to pravi put, jer bi on zahtevao više meseci. ${ }^{27}$ U Hrvatskoj je bilo gunđanja, pa je list Jugoslavenski lojd pozivao sve na saradnju. ${ }^{28}$ Ubrzo zatim, marta 1919, markiranje su izvele Čehoslovačka i Austrija, zatim i drugi. Ipak, žigovi i markice nisu predstavljali veliku prepreku za vlasnike kruna i na njihovim interesima zasnovanu privatnu inicijativu - ni da napuste jednu zemlju ni da se legalizuju u drugoj.

Žigosanje je završeno do 31. januara 1919. godine. Ukupan iznos žigosanih kruna bio je 5.323 miliona, od čega u Hrvatskoj i Slavoniji (sa Sremom) 1.949, Banatu i Bačkoj 1.669, Sloveniji 603, Bosni i Hercegovini 512, Srbiji (u predratnim granicama) 421, Dalmaciji 163 i Crnoj Gori $6 .^{29}$ Kako se vidi, najviše kruna žigosano je u Hrvatskoj i Slavoniji (sa Sremom) 36,6\% i Bačkoj i Banatu 31,4\%, a znatno manje u Sloveniji (11,3\%) i Srbiji u predratnim granicama (7,9\%). Svi ovi brojevi ne moraju da predstavljaju tačno stanje pošto je moguće da je pred žigosanje došlo (1) do priliva kruna iz drugih zemalja i (2) do nepodnošenja postojećih kruna na žigosanje kako bi ih bilo moguće koristiti u drugim zemljama. Verovatno su transakcione krune, one koje drže građani, uglavnom podnete na žigosanje, dok deo špekulativnih nije. Velimir Bajkić je, međutim, smatrao da je „neozbiljno“ verovati kako su ovo tačne brojke iz drugih razloga - „dezorganizacije vlasti i potpune podvojenosti između centralne vlasti i onih raznih vlasti koje su vršile žigosanje“, ${ }^{30}$ dok je Milorad Nedeljković bio istog mišljenja i naveo da „mnoge civilne i vojne ustanove“ nisu poslale izveštaje o vrednosti kruna koje su markirale. $^{31}$

Žigosanje je postiglo jedan cilj - postavljanje monetarne demarkacione linije prema austrougarskoj kruni - ali ne i drugi, jer priliv nežigosanih kruna nije onemogućen usled slabe tehnike žigosanja: izvršeno je običnim, međusobno različitim pečatima, uključujući i austrougarske na stranim jezicima, a s običnim mastilom, pa su žigovi veoma lako falsifikovani. Čak, građani nisu ni mogli da znaju da li je žig na novčanici u njihovim rukama valjan ili nije. Slično tome, statistički razlog je ubrzo nestao jer je stanje zastarelo. Ipak, žigosanje je donekle umirilo posednike kruna pošto je postalo očigledno da država neće krune proglasiti ništavnim.

${ }^{27}$ M. Nedeljković, Naš valutni problem, Beograd, februar 1919, 14.

${ }^{28}$ Jugoslavenski Lloyd, 8. januar 1919.

${ }^{29}$ Narodna banka 1884-1934, 140.

${ }^{30}$ V. Bajkić, n. d., 103.

${ }^{31}$ M. Nedeljković, Pred rešenje valutnog pitanja, Zagreb 1919, 3. 


\section{Duga 1919.}

Plan ministra Ninčića bio je da se (1) da se izradi „nacionalna novčanica“, tj. državni novac kojim će se zameniti kruna; državni stoga što se nije htelo čekati na ozakonjenje nove emisione banke, pošto bi se tako izgubili meseci; (2) da se tom novcu dâ "povoljna vrednost" kako bi stekao poverenje publike i (3) da se srede državne finansije kako bi se omogućila novčana stabilnost. ${ }^{32}$ Već 1 . februara 1919. Vlada je donela odluku da se što pre izda državni papirni novac koji glasi na dinare i kojim će se zameniti krunske novčanice po kursu koji će kasnije biti određen. ${ }^{33} \mathrm{U}$ tom cilju ubrzo je ugovoreno štampanje državnih novčanica za 3,5 milijardi u Parizu, a potom i Pragu i Zagrebu. Posao štampanja se, međutim, otegao. Prolazili su meseci, a novac nije stizao. ${ }^{34}$ Ministar Ninčić pravdao je zakašnjenje tehničkim razlozima (zauzetost pariske štamparije, nedostatak papira, boje i rezervnih delova). U maju je štampa javljala da novčanice stižu na leto, kada su zaista i počele da pristižu, ali vrlo sporim tempom, što se razvuklo do kraja godine. U septembru ih je bilo naštampano oko jedne milijarde dinara, a u novembru 2,1 milijarda dinara, od čega je u zemlju došlo tek oko 800 miliona. ${ }^{35}$

U proleće 1919. Vlada je organizovala više konferencija s privrednicima kako bi ih upoznala sa svojim planovima i čula njihovo mišljenje.

Istovremeno su tekli pregovori sa Upravnim odborom Narodne banke o njenoj transformaciji i o valutnoj reformi i dogovor je postignut krajem juna, pa je pripremljen i nacrt zakona. Narodna banka je pristala da poručene državne novčanice emituje kao svoje i da njena podloga fundira i staru srpsku i novu državnu novčanicu, s tim da prihod od dela državnih domena posluži za dugoročni rast podloge. ${ }^{36}$ Tokom leta se razbuktala politička kriza, sa promenom vlade (Protić-Davidović) i ministra finansija (Ninčić-Veljković), što je usporilo aktivnosti.

Pošto se pročulo da zamena kruna, zbog sporog priticanja štampanih državnih dinara, neće biti moguća pre maja 1920, Ivo Belin je predlagao da se zamena izvrši srpskim dinarima, pošto se oni, kao već postojeća valuta sa klišeima, mogu znatno brže naštampati. A na eventualne primedbe zbog upotrebe srpskih dinara, tvrdio je da su privredni interesi važniji od interesa

${ }^{32}$ M. Ninčić, $n$. d., 27-28.

${ }^{33}$ Ministarstvo finansija Kraljevine Jugoslavije 1918-1938, Beograd, 216.

${ }^{34}$ Čehoslovački ministar finansija Rašin je istovremeno tražio štampariju novčanica, ali, kako je naveo, čak ni velike američke nisu prihvatale rok isporuke kraći od šest meseci. - A. Rašin, Financial Policy of Czechoslovakia During the First Year of Its History, Oxford, 1923, 19. vembar 1919.

${ }^{35}$ Trgovinski glasnik, 10. maj 1919; Politika, 9. septembar 1919; Politika, 7. no-

${ }^{36}$ M. Ninčić, $n$. d., 30. 
„raznih šovena i separatista“. Što se tiče priliva kruna sve je bilo po starom: „Još uvijek se importiraju austro-ugarske novčanice. Jedan se dio tih kruna ovdje legalnim ili nelegalnim putem žigoše, dok drugi dio i nežigosan dolazi u promet ${ }^{\text {" }}{ }^{37}$

Odlaganje rešenja izazivalo je nezadovoljstvo. Tako je Trgovinski glasnik tvrdio sredinom godine da je privredni rad „ukočen“ zbog nerešenog valutnog pitanja i gotovo besno poručivao vlastima: „zahtevamo najhitnije njegovo rešenje; ako to nije moguće pomoću Narodne banke Kraljevine Srba, Hrvata i Slovenaca i preko nje, a ono putem državnog papirnog novca, i to što pre, odmah". ${ }^{38}$

Istovremeno je trajala kampanja dvaju tabora u korist svojih koncepata: vladina i vladinih oponenata, uglavnom iz Zagreba i Ljubljane. Vladini predstavnici su tvrdili da zastupaju srednju liniju između ekstrema, pa je tako Nedeljković rekao da „isplata krune po punoj nominalnoj vrednosti zaista bi bilo suviše veliko i nepravično opterećenje države“. Ali, „isto tako nije ni pravo ni pametno sasvim ubiti vrednost krune... jer bi time... mnogi ljudi bili nepravično pogođeni“. Stoga je verovao „da će rešenje morati poći nekom srednjom linijom... putem kompromisa“. ${ }^{39}$ I ministar finansija Vojislav Veljković govorio je da nije njegova namera da „pobija“ vrednost krune i da poništava krune uz minimalnu naknadu (1:10 i manje), što je predlagano, ali i da al pari zamena (kruna dinar 1:1) nije prihvatljiva. ${ }^{40}$

$\mathrm{S}$ druge strane barikade, pominjalo se „ubijanje jugoslovenske krune“ kojim se postiže „uništenje $3 / 4$ imovine našeg stanovništva“, pri čemu "režiseri" manipulišu beogradskom berzom i sve to se naziva "herostratskim činom". ${ }^{41}$

Pored pitanja zamene kruna i unifikacije novca, pojedini autori su videli mogućnost da se tom operacijom smanji količina novca u opticaju na bolju meru. Tako je Nedeljković procenjivao da kruna trenutno ima 8 do 9 milijardi, što je svakako "suviše“, a da je 2 milijarde dinara "dovoljno" za zamenu kruna i „zdrav“ novčani opticaj, polazeći od trenutnih cena („skupoće“), nerazvijenosti bezgotovinskog plaćanja, tezauracije novca i „življeg ekonomskog prometa“. ${ }^{22}$ Slično je mišljenje bivšeg ministra Ninčića, koji je verovao da je suviše novca $u$ prometu i da bi ga trebalo smanjiti kroz zamenu. ${ }^{43}$ I u Zagrebu je bilo mišljenja da treba smanjiti opticaj kruna na polovi-

${ }^{37}$ I. Belin, Financijalna politika u našoj državi, Jugoslavenska njiva, 6. septembar $1919,571$.

${ }^{38}$ Trgovinski glasnik, 27. juni 1919.

${ }^{39}$ M. Nedeljković, Naš valutni problem, 18-24.

${ }^{40}$ Pravda, 31. oktobar 1919.

${ }^{41}$ Naša imovina u opasnosti, Slovenski narod, 10. decembar 1919.

${ }^{42} \mathrm{M}$. Nedeljković, Pred rešenje valutnog pitanja, 4-6.

${ }^{43}$ M. Ninčić, Naše valutno pitanje, 9. 
nu kako bi ojačao njen kurs, pa ili kroz porez ili kroz zadržavanje polovine pri razmeni za dinare. ${ }^{44} \mathrm{U}$ Ljubljani je Milko Brezigar, takođe, bio za bitnu redukciju krunskog opticaja. Ideja o smanjenju opticaja bila je veoma raširena u Evropi posle Prvog svetskog rata kao deo programa povratka na predratne vrednosti novca kroz deflaciju i jačanje valuta.

\section{Markiranje kruna}

Pred kraj 1919. došlo je vreme za valutni rasplet, pošto je početkom decembra u zemlji bilo novčanica za dve i po milijarde dinara. ${ }^{45}$ Od 26. novembra 1919. do 11. januara 1920. izvršeno je markiranje kruna, to jest na svaku krunsku novčanicu, osim sitnih, zalepljena je specijalna markica. Sto miliona markica štampano je u Beču i plaćeno, zajedno s priznanicama, kako kaže Bajkić, samo sa dva vagona brašna i jednim vagonom slanine. Zagrebački stručnjaci su procenjivali da dobro izrađena markica može da se bori s falsifikatorima tri meseca, što je bilo dovoljno za pravu zamenu kruna. ${ }^{46}$ Nestrpljivima je markiranje ličilo na otezanje: tako je Politika pitala „da li je ovaj ogromni posao oko markiranja, ovo užasno gubljenje vremena i za činovnike i za publiku... bilo potrebno?... Zašto se od jednog posla prave dva?" ${ }^{47}$ misleći na predstojeću zamenu kruna.

Markiranjem su obuhvaćene samo žigosane novčanice. Da nedužni građani ne bi bili oštećeni, rešeno je da se sve sporne žigosane novčanice markiraju, čime su legalizovane i one s falsifikovanim žigovima. ${ }^{48}$ Nisu markirane sitne novčanice, od 1, 2 i 10 kruna. Oko konačnih rezultata postoje ozbiljne nesuglasice.

Po Narodnoj banci, ukupno je markirano 5.687 miliona kruna, ${ }^{49} \mathrm{a}$ po Ministarstvu finansija, za markiranje je bilo prijavljeno 4,6 milijarde kruna. ${ }^{50}$ Ne znamo uzrok ove velike razlike. Bilo kako bilo, markirano je manje od očekivane sume. Slovenec je preneo mišljenje da su se mnogi uzdržali od markiranja i svoje nemarkirane krune preneli u okupirana područja Dalmacije, Primorja i Baranje nadajući se da će ih država, kada ta područja

${ }^{44}$ Obzor, 1. mart 1919.

${ }^{45}$ Trgovinski glasnik, 4. decembar 1919.

${ }^{46}$ V. Bajkić, n. d., 105.

${ }^{47}$ Politika, 21. novembar 1919.

48 „Falsifikati žigova postali su toliko brojni da zvaničnici ni sami više nisu mogli da detektuju da li je žig originalan ili falsifikovan tako da je vlada bila primorana da prihvati veliku količinu falsifikovanih novčanica kada su podnete na drugo žigosanje“. - J. van Walre de Bordes, The Austrian Crown, P. S. King, 1924, 9.

${ }^{49}$ Narodna banka 1884-1934, 141.

${ }^{50}$ Ministarstvo finansija Kraljevine Jugoslavije 1918-1938, 216. 
budu pripojena Jugoslaviji, prihvatiti i zameniti ih, pa da će tako izbeći zadržavanje onih $20 \%{ }^{51}$

Razloga za markiranje bila su dva. Prvi, da se utvrdi približan broj kruna u prometu, kako bi se videlo kada će, s obzirom na priliv novoštampanih novčanica, biti moguće izvršiti zamenu kruna. Drugi, i važniji, jeste zadržavanje $20 \%$ od iznosa markiranih kruna u korist državnog budžeta kao prinudni zajam. Ova mera je, kako kaže tadašnji pomoćnik ministra finansija Bajkić, „diktirana čisto finansijskim razlozima“, jer je državi bio potreban prihod u krunama radi plaćanja na krunskom području, a njega iz redovnih prihoda nije bilo dovoljno. ${ }^{52}$ I Ivo Belin misli da je ovo zadržavanje „imalo za glavni cilj da pribavi državi nova sredstva“. ${ }^{53}$ Pošto dinarske novčanice, koje su lako doštampavane, nisu primane na krunskom području kao nepoznate, država se dovijala za pokriće manjka prihoda u krunama: ovo je bio jedan, a drugi pomenuta nabavka 300 miliona kruna iz Austrije radi zamene pohabanih novčanica, koja nije izvršena. Zadržavanje ovih $20 \%$ kruna nije bilo trajno: Vlada se obavezala da će ih vratiti, ali je ovo zadržavanje kod mnogih u prečanskim krajevima doživljeno kao konfiskacija. Prvobitno rešenje bilo je sledeće: rok pet godina, kamatna stopa $1 \%$. Kasnije je menjano više puta, da bi konačno Finansijskim zakonom za 1929/30. godinu bilo propisano da se priznanicama mogu plaćati poreske obaveze i finansijske kazne. ${ }^{54}$ Ovo zadržavanje kruna nije nepravedno kao što izgleda. Ono predstavlja monetarni doprinos krunskog područja pokrivanju budžetskog deficita, koji je dinarsko područje već pokrivalo inflatornom monetarnom emisijom, to jest smanjenjem vrednosti dinara na teret njegovih posednika.

Moguće je da je postojao i drugi razlog za zadržavanje $20 \%$ kruna, mada ga niko ne pominje: ono je u određenoj meri odvraćalo priliv kruna iz inostranstva. Jer, time su se pogoršavali uslovi razmene kruna za dinare i podsticali vlasnici milijardi kruna da potraže povoljniju opciju u drugim zemljama.

Kraljevina SHS je na kraju prošla relativno dobro i izbegla je veliki priliv iz inostranstva, jer niti je nudila najpovoljnije uslove niti je poslednja zamenjivala krune. Nikakvi podaci, naravno, o ovome ne postoje, već samo grube procene. Upravni odbor Narodne banke verovao je pred markiranje da kruna u zemlji ima $8-10$ milijardi. ${ }^{55}$ Da li je ovo bila potpuno pogrešna procena, jer je za markiranje prijavljeno daleko manje, ili je znatan deo oti-

${ }^{51}$ Slovenec, 17. decembar 1919.

${ }^{52}$ V. Bajkić, n. d., 110.

${ }^{53}$ I. Belin, Poslije valutne reforme, Jugoslavenska njiva, 12. juni 1920, 372.

${ }^{54}$ Detaljnije: I. Becić, Finansijska politika Kraljevine SHS 1918-1923, Beograd 2003, 135.

${ }^{55}$ Lj. Kosier, n. d., 192. 
šao preko granice nije izvesno. Da je skidanje starih žigova bilo masovna pojava svedoči Bajkić, koji kaže da je „prilična suma krunskih novčanica ostala uopšte nemarkirana. Jedan deo imalaca radije se rešio da pere žig sa novčanica (što je docnije, posle svršenog markiranja, postala naročita industrija) i da je proda u inostranstvo, nego da se izlaže štrapacima oko markiranja, pa uz to dâ još i državi $20 \%$ ". ${ }^{56}$

\section{Kretanje kursa krune}

Videli smo da je austrougarska kruna brzo gubila vrednost tokom 1919. U Jugoslaviji je pad vrednosti krune uopšte i prema dinaru bio znatno sporiji. Pogledajmo kretanje kursa na Beogradskoj berzi između sredine februara $1919 .^{57}$ i sredine januara 1920 (tačkasta linija):

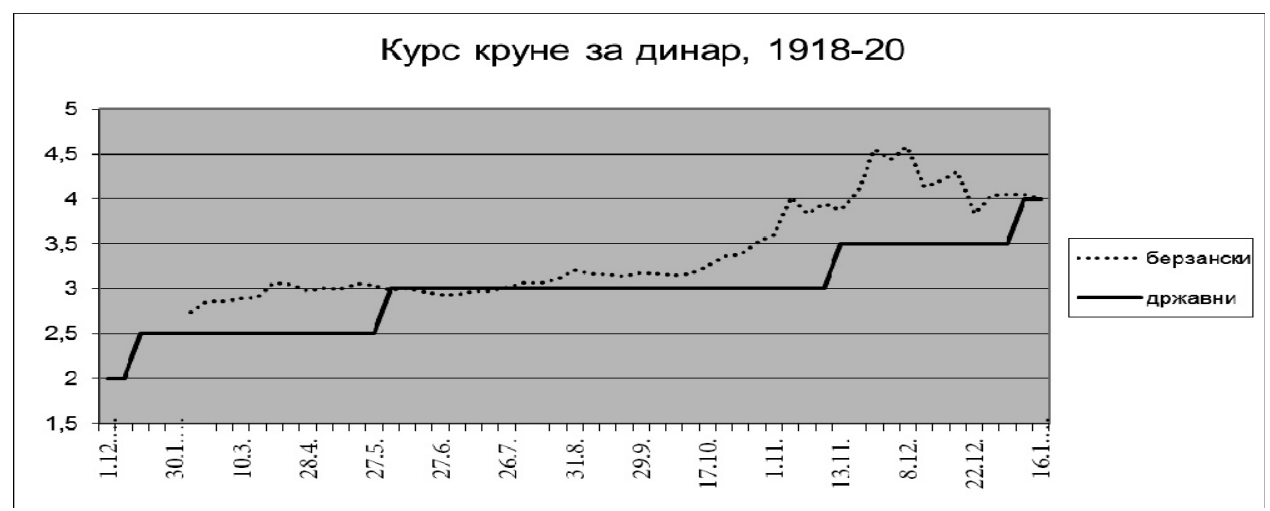

Izvor: Trgovinski glasnik i Službene novine, razni brojevi

Tačkasta linija pokazuje da je sredinom februara 1919. jedan dinar na berzi vredeo 2,7 kruna, a sredinom januara 1920. godine 4 krune. Takvom relativno malom padu vrednosti krune pripomogao je i dinar, čija je vrednost prema stabilnim valutama takođe opadala.

Osnovna determinanta kretanja kursa domaće žigosane krune bilo je propadanje austrijske krune na evropskim berzama. Kada se kurs dolara u Beču decembra 1919. kretao oko 150 kruna, ${ }^{58}$ onda nije čudno da se istovremeno kurs u Zagrebu kretao oko 100 kruna za dolar. ${ }^{59}$ Ova razlika posledica je činjenice da žigosana SHS kruna nije bila jednaka austrijskoj kruni,

\footnotetext{
${ }^{56}$ V. Bajkić, n. d., 106.

${ }^{57} \mathrm{Ne}$ postoje podaci za raniji period, jer je berza obnovila rad 17. februara 1919.

${ }^{58} \mathrm{~J}$. van Walre de Bordes, $n$. d., 116.

${ }^{59}$ Trgovinski glasnik, razni brojevi.
} 
već se radilo o dve varijante jedne valute. ${ }^{60}$ Čak, da nije bilo mogućnosti za falsifikovanje i prelivanje, SHS kruna bi mogla biti stabilna valuta jer nove emisije nije bilo, za razliku od dinara čiji se opticaj povećavao i vrednost padala. Međutim, mogućnost lakog falsifikovanja omogućavala je prelaz iz jedne u drugu krunu, a što se odražavalo na kretanje kursa. Dovoljno je, čak, da postoji mogućnost prelivanja pa da sudbina dveju kruna bude bitno povezana: pad krune u Austriji donosio je pad i u Jugoslaviji.

Ovom osnovnom trendu doprinosio je špekulativni faktor, odnosno neizvesnost o budućem kursu zamene krune, zajedno sa pratećim glasinama, što je povremeno dovodilo do skokova i padova. Jedna epizoda je s početka septembra 1919: na pojavu glasova da će se kruna zameniti u odnosu 4:1, a možda čak i 5:1, povećana je ponuda kruna i njen kurs je pao. Ali, na vest $u$ jednim novinama da će relacija verovatno biti 3:1, kurs se počeo popravljati ${ }^{61}$ i vratio se na stari nivo. Druga epizoda vidljiva na prethodnom grafikonu: kruna je u drugoj polovini novembra oslabila na 4,5 kruna za dinar i tu ostala nekoliko nedelja. Pad je nastao verovatno stoga što je dosta posednika pokušalo da se reši kruna bez markiranja i zadržavanja $20 \%$, pa je ponuda bila povećana i kurs pao. Potom je kruna ojačala na 4 za dinar i tu se zadržala do zamene. Kako se vidi, takvi povremeni zaokreti nisu trajali dugo, jer su glasine bile nepouzdane i stoga kratkog dejstva, a kurs se vraćao na stabilnu tendenciju. Niko nije ni mogao znati koliki će konačni kurs biti jer je dogovoren tek pred sam kraj decembra 1919, posle teških pregovora unutar koalicione vlade, gde su većinu činili ministri iz prečanskih krajeva (Bjankini, Trumbić, Korać, Alaupović, Kramer, Krizman, Bukšeg, Pribićević, Kristan, Palaček, Luknić).

Oko 1. decembra 1919. pominju se pokušaji manipulacije kursom. Trgovinski glasnik javlja o velikim kupovinama kruna od strane nekih banaka sa krunskog područja koje time navodno pokušavaju da održe berzanski kurs krune na što višem nivou u vreme kada se odlučuje o kursu zamene dveju valuta. ${ }^{62}$ I druga strana tvrdi to isto, samo u suprotnom smeru: Ivan Krajač pominje desetine miliona kruna koje su „neki Aškenazi i Alkalaj“ bacili na berzu ne bi li joj oborili kurs. ${ }^{63}$

Pred Novu 1920. pročulo se pouzdano da će konačni kurs biti 4:1, ${ }^{64}$ pa se i berzanski kurs smirio na toj vrednosti.

${ }^{60}$ Teorijski, visina kursne razlike određena je troškovima falsifikovanja, uključujući i rizik otkrivanja falsifikata, oduzimanja novca i kazne.

${ }^{61}$ Trgovinski glasnik, 9. septembar 1919; tokom prethodnih sedam dana prosečni dnevni kurs kretao se u dosta uskom rasponu (3,10 do 3,19, tj. unutar 2,9\%), pa dinamika kursa nije bila dramatična.

${ }^{62}$ Trgovinski glasnik, 3. decembar 1919.

${ }^{63}$ Lj. Kosier, $n$. d., 197.

${ }^{64}$ Trgovinski glasnik, 3. januar 1920. 
Neposredan uticaj države na dugoročno kretanje kursa ovih dveju valuta u bilo kom smeru mogao je da bude skroman. Jer, ona nije kupovala i prodavala valute na deviznom tržištu kako bi vodila politiku kursa bilo koje valute, tj. nije na njemu ni učestvovala. Može se pomisliti da je uticaj mogao postojati preko zvanično objavljivanog kursa koji je sama vlada primenjivala u svojim transakcijama s privatnim sektorom (plaćanje dažbina, državne nabavke i slično). On se kretao ovako:

Državni kurs krune prema dinaru, 1918-1920.

\begin{tabular}{|l|c|c|c|c|c|}
\hline Važi od & $\begin{array}{c}30.10 . \\
1918 .\end{array}$ & 1.1 .1919$. & 5.6 .1919$. & $\begin{array}{c}11.11 . \\
1919 .\end{array}$ & 1.1 .1920$. \\
\hline $\begin{array}{l}\text { Kurs } \\
\text { kruna/dinar }\end{array}$ & 2 & 2,5 & 3 & 3,5 & 4 \\
\hline
\end{tabular}

Izvori: za 30. 10. 1918. Srpske novine, 6. novembar 1918; za 1. 1. 1919. Službene novine, 12. januar 1919; za 5. 6. 1919. Uradni list, 27. juni 1919; za 11. 11. 1919. Službene novine, 16. novembar 1919; za 1.1.1920 Službene novine, 6. januar 1920.

Ipak, neposredan uticaj državnog na tržišni kurs nije mogao biti važan, iz dva razloga. Prvo, kako se vidi upoređenjem kretanja državnog i tržišnog kursa na prethodnom grafikonu, državni kurs se sa određenim vremenskim zakašnjenjem prilagođavao tržišnom, što znači da je pratio, a ne vodio. I drugo, obim transakcija po državnom kursu bio je skroman. Ne raspolažemo nikakvim podacima o tome, ali znamo da je država tokom 1919. poslovala s krunama na krunskom i dinarima na dinarskom području, a da su jedina odstupanja postojala kod eventualnih plaćanja dažbina u krunama na dinarskom području i, kasnije tokom 1919, isplate nekih plata u dinarima na krunskom području. To su, svakako, bili skromni iznosi koji nisu mogli uticati na berzanski kurs.

Ivo Banac je pokušao da diskredituje tekući kurs krune i dinara kao osnovu konačne relacije po kojoj će se izvršiti zamena tvrdnjom o „politički motivisanoj Beogradskoj berzi“ ${ }^{65}$ bez ikakvog argumenta. Ovo je, svakako, veliki pronalazak suprotan viševekovnom uverenju ekonomske nauke da berzanske igrače isključivo pokreću lukrativni motivi, a ne bilo čiji politički interesi. Polazeći od pretpostavke da zagrebačka berza nije bila politički motivisana, pogledaćemo tamošnje kurseve i uporediti ih sa beogradskim. Tako je, na primer, 31. oktobra 1919. na zagrebačkoj berzi jedan dolar vredeo 66,75 kruna, a na beogradskoj 19,2 dinara, iz čega proizlazi da dinar vredi 3,5 kruna, tačno toliko koliki je njihov kurs bio istog dana u Beogra-

\footnotetext{
${ }^{65}$ I. Banac, The National Question in Yugoslavia: Origins, History, Politics, Cornell,
} $1988,223$. 
du. Ili, 13. decembra 1919. kurs dinara na zagrebačkoj berzi bio je 4,15 kruna, a na beogradskoj 4,2 krune. ${ }^{66}$ Možda će istoričaru s političkim preferencijama čudno izgledati savršeno slaganje kurseva u Beogradu i Zagrebu, ali ekonomistima neće: dovoljna je jedna reč - tržište, bez političke motivisanosti bilo koje berze.

\section{Narodna banka}

Narodna banka Srbije je za vreme rata bila smeštena u Marseju. Vratila se u Beograd 16. februara 1919 (po starom), a dvomesečno odlaganje opravdavano je rutiniranošću njene zgrade u Beogradu i nespremnošću da se „sve bančine, državne i privatne vrednosti“, što uključuje i metalnu podlogu, prevoze morem pošto je to, zbog brojnih mina, „veoma opasan“ put. Voz je obezbeđen tek za 6 . februar. ${ }^{67}$

Važnije, odmah se postavilo pitanje stvaranja centralne banke Kraljevine SHS. Glavni ideja neminovno je bila transformacija srpske u jugoslovensku banku s obzirom na njenu stručnu i tehničku kompetenciju i metalnu podlogu, kao i dobar rad tokom prethodnih decenija. Pregovori vlade i Narodne banke okončani su dogovorom početkom juna 1919. Ministar trgovine Veljković je već jula podneo ekspoze u Skupštini kojim je predložio transformaciju banke, uz sugestiju o proširenju osnovnog kapitala čime bi se pružila prilika i drugima da upišu njene akcije i postanu suvlasnici ove inače privatne ustanove s javnim ovlašćenjima. Založio se i za zlatno važenje dinara, doduše ne odmah, a zbog ratnih posledica. U pogledu važne dileme - da li krune zameniti državnim ili bančinim novčanicama - založio se za bančine iako to donosi državi veliki dug kod Narodne banke (zbog podloge) i odlaganje zamenljivosti novčanica za plemeniti metal. Kao razlog $\mathrm{u}$ korist bančinih novčanica naveo je strožu monetarnu politiku, ${ }^{68}$ odnosno iskustvenu činjenicu da se nezavisne centralne banke bolje brinu o kvalitetu novca nego ministarstva finansija, koja su često, zbog budžeta, sklona emisiji novca bez pokrića.

U poslednjem trenutku pred usvajanje zakona o Narodnoj banci januara 1920, povećani su okviri dozvoljenog zaduživanja države kod banke. Zakon je potvrđen 26. januara 1920, a ona je počela da radi pod novim imenom 1. februara. Sledećih godina povećan je kapital javnim upisom 40.000 akcija, pored 20.000 postojećih. Postojeći akcionari nisu imali prednost. Upis je išao slabo i trajao je od jeseni 1920. do 2. marta 1922, pa je svako imao priliku da ostvari većinsko vlasništvo. Interesovanje je, među-

\footnotetext{
${ }^{66}$ Trgovinski glasnik, 14. i 17. decembar 1919.

${ }^{67}$ Izveštaj o radu Narodne banke za 1919, prema Lj. Kosier, n. d., 185.

${ }^{68}$ Lj. Kosier, n. d., 187-188.
} 
tim, bilo skromno i tek je poslednjih dana upisana velika količina akcija i upis okončan. Većinsko vlasništvo ostalo je u Srbiji. ${ }^{69}$

\section{Alternativni predlog unifikacije}

Predloga za rešenje valutnog pitanja bilo je više. Za najvažniji alternativni može se smatrati avgustovski predlog Saveza novčanih zavoda iz Zagreba, budući da je obuhvatao brojne finansijske institucije i uticao na tamošnje poglede. Njegovi elementi su sledeći (elementi predloga dati su kurzivom, ostalo je moj komentar): $:^{70}$

- izdaje se novi državni novac, čiji je naziv dinar; takvim stvaranjem državnog novca bez metalnog pokrića otklanja se prigovor kruni - da samo ona nema pokriće - pa se dve postojeće novčanice ravnopravno menjaju za novu; odsustvo podloge učinilo bi novi dinar slabijom valutom od dinara Narodne banke;

- kruna se zamenjuje za novi dinar al pari; time se, psihološki (kroz zadržavanje istih nominalnih vrednosti), olakšava prihvatanje dinara na krunskom području, ali otežava na dinarskom; važnije, ova relacija prouzrokovala je u svoje vreme u štampi i politici najviše zle krvi, bez suštinskog razloga, čak besmisleno; naime:

- mnogi prečani bezrazložno su verovali da bi slabiji kurs krune doneo ogromne gubitke $u$ individualnoj i nacionalnoj imovini i bili spremni da predlog brane do poslednje kapi krvi,

- mnogi Srbijanci bezrazložno su verovali da bi prihvatanje ovog kursa anuliralo krivicu AU banke i nepravedno nagradilo ratne profitere preko državnog budžeta, kome i postradali narod treba da doprinosi; ${ }^{71}$ međutim:

- posmatran sam za sebe, potpuno je svejedno koji se kurs između krune i novog državnog dinara odredi; ništa se suštinski ne menja da li je to 1:1, 1:10 ili 1:100, pošto će se nivo cena, uz pomoć kvantitativne teorije novca, uskladiti s kursom i novčanim opticajem; ono što je presudno i što je zaokruživalo koncept jeste sledeća tačka kao dopuna ove:

- jedan srpski dinar se zamenjuje sa dva nova dinara; na ovaj način dobijen je za ceo problem najvažniji kurs - žigosana kruna-srpski dinar od 2:1 - što je postalo raširen prečanski predlog (Avakumović, Bićanić); poslednje dve relacije uzete zajedno trebalo je da budu predmet polemike, a ne samo ona iz prethodne tačke; inače, ovo odstupanje od al pari-a, koji bi

${ }^{69}$ Narodna banka 1884-1934, 115-119.

${ }^{70}$ Spomenica Saveza novčanih zavoda Kraljevstva SHS, Zagreb 1919, 18-19.

${ }^{71}$ Tako su rezonovali Milorad Nedeljković (Pred rešenje valutnog pitanja, 17-18) i Momčilo Ninčić (Lj. Kosier, n. d., 268). 
bio zasnovan na navodnoj jednakosti kupovne moći, obrazloženo je kao kompenzacija za okupacionu zamenu dinara za krune po kursu 2:1;

- ceo iznos za zamenjene krune ne bi bio isplaćen odmah već samo 50\%; ostatak bi bio isplaćen za godinu ili godinu i po, a u međuvremenu bi se mogao koristiti za plaćanje poreza; ovom pozajmicom bi kratkoročno bio olakšan finansijski položaj države, što je izgledalo kao mamac;

- državni dinar bio bi zamenjen novčanicama Narodne banke onda kada mu se obezbedi podloga; ovo znači da bi novi državni novac zadugo bio jedino sredstvo plaćanja, a Narodna banka, sa svojom podlogom, isključena iz monetarnih poslova.

Ovaj predlog bio je posebno problematičan u dve tačke. Prvo, oslonac na državni novac, odnosno odustajanje od metalne podloge smatrano je rizičnim potezom usled sklonosti država da svoje deficite finansiraju iz monetarne emisije, ${ }^{72}$ čime se novac kvari i uvodi inflacioni porez. I drugo, predlog kursa zamene krune za srpske dinare od 2:1 bio je korak u dobrom pravcu, jer je odustajao od čestog hrvatskog zahteva o kursu 1:1, ali nedovoljno za mnoge, uključujući Vladu i skupštinsku većinu.

Korekcija ovog plana sugerisana je 11. januara 1920, u danima zasedanja vlade o valutnoj reformi. Konferencija privredničkih i finansijskih organizacija uglavnom iz Zagreba i Ljubljane zamenila je tačku o odnosu novi dinar prema srpskom dinaru kao 2:1, tekstom da će se konačna relacija kasnije ustanoviti, s tim da srpski dinar dobije višu vrednost nego novi dinar. ${ }^{73}$ Prihvatanje ove korekcije donelo bi zamenu krune novim dinarom, ali i zadržavanje srpskog dinara u prometu kao druge valute sa sopstvenom podlogom. Time bi se rešilo krunsko pitanje, ali bi ostalo dvovalutno stanje u zemlji. Odnosno ovim bi se trenutno ublažio politički problem, ali po cenu odlaganja unifikacije novca, sa konkurencijom dveju novčanica.

\section{ZAMENA KRUNA}

\section{Krunsko-dinarska novčanica}

U decembru 1919. aktivnost je ubrzana. Petnaestog decembra održana je konferencija na kojoj su učestvovali u ime Vlade ministar Veljković, njegov pomoćnik Velimir Bajkić, ministar trgovine Kramer, njegov pomoćnik Milan Radosavljević, kao i Milko Brezigar, Ivan Krajač i Juraj Vrbanić, direktor Prve hrvatske štedionice. Poslednja dvojica se nisu složila sa Veljkovićevim planom. ${ }^{74}$

${ }^{72}$ Videti kritiku papirnog novca i zalaganje za zlatni standard u V. Lunaček, Problem uređenja naše valute, Jugoslavenska njiva, 20. decembar 1919.

${ }^{73} \mathrm{Lj}$. Kosier, $n$. d., 304.

${ }^{74}$ Edinost, 29. decembar 1919. 
Da će se zamena ubrzo obaviti definitivno se saznalo pred kraj decembra. Tako je Pravda, bliska Vladi, javila 23. decembra 1919. sve bitne elemente: da će biti izdati dinari Narodne banke, da će kurs verovatno biti 4:1, koliko predlaže ministar, i da će zamena ubrzo početi, jer se već raspolaže dovoljnom količinom dinarskih novčanica za zamenu procenjenih 6-7 milijardi kruna. ${ }^{75}$

U dane konačne odluke, tokom januara 1920, temperatura je veoma porasla i odmah je započela oštra svađa. Zagrebački list Hrvat, organ Hrvatske zajednice, nazvao je to „ordinarnom pljačkom" i uništenjem „tri četvrtine svoje novčane imovine" što je mogao izvesti samo "destruktivan duh". A Trgovinski glasnik je odgovarao da kruna više nema nikakvu svoju vrednost, već da joj vrednost daje država svojim „privremenim prihvatanjem“. Stoga je zahteve za zamenom al pari odbacio ocenivši da bi to značilo „da se imaocima kruna dade 4-5 veća vrednost od one koja se zamenjuje“, uz inflaciju i sve terete za državu. Pomenut je i separatizam. ${ }^{76}$

U javnosti su cirkulisali različiti predlozi: pomenut predlog Saveza novčanih zavoda da se kurs krune i srpskog dinara za sada ne utvrđuje; ili, Matka Laginje, šefa Narodnog kluba i Hrvatske zajednice, koji je u pismu premijeru Davidoviću zahtevao kurs al pari. I u samoj vladi su razmatrane različite opcije, doduše sve s kursom $4: 1{ }^{77}$ Unutar vlade nastala je i kriza, jer se ministar Kramer usprotivio nekim rešenjima, pa je izlaz nađen $u$ krunsko-dinarskoj novčanici. To je slovenačkim demokratama poslužilo kao odstupnica, pa je predsednik slovenačke vlade Gregor Žerjav rekao da „relacija nije glavna stvar... jer smo mi spremni dinar otkupljivati za četiri krune samo da kruna ostane jedinica". ${ }^{78}$

Vlada je 13. januara formalno donela potrebne odluke, koje su potpisali svi ministri: ${ }^{79}$ da Narodna banka izdaje krunsko-dinarsku novčanicu, koja će imati odštampane iznose i u krunama i u dinarima, a uz odnos 4 krune jedan dinar (na primer, 100 dinara i 400 kruna); da se i austrougarska kruna i srpski dinar zamenjuju za novu novčanicu al pari, ali kruna za krunu, a dinar za dinar; da u opticaju ostaju sitne krunske novčanice; da državne blagajne računaju i u krunama i u dinarima; da krunsko-dinarska novčanica po zameni postaje jedino sredstvo plaćanja. Odnos 4:1 vlada je

${ }^{75}$ Pravda, 23. decembar 1919.

${ }^{76}$ Trgovinski glasnik, 11. januar 1920.

${ }^{77}$ Izgleda da su razmatrana još dva koncepta: prvi, potekao iz Slovenije, po kome se za novi bančin dinar kruna menja al pari, a srpski dinar za četiri nova; i drugi, po kome bi nove novčanice glasile na krune, a stare krune menjale za nove al pari, dok bi srpski dinar ostao u opticaju i inicijalno imao propisani kurs 1:4 u odnosu na novu krunu. - Slovenec, 20. januar 1920.

${ }^{78}$ Politika, 11. januar 1920, 13. januar 1919; Slovenski narod, 15. januar 1920.

${ }^{79}$ Politika, 14. januar 1920. 
smatrala, kako je navela, kao „postulat pravde“ jer se na tržištu toliko može dobiti, pa ne bi bilo pravo da država dâ manje. ${ }^{80}$ Pravo na zamenu imalo se samo za markirane krune. One su zamenjene ranije naručenim državnim novčanicama, koje je Narodna banka pustila u opticaj kao svoje, pa je važila postojeća metalna podloga.

Pošto je zadržano ime krune, ova inteligentna kombinacija olakšala je prihvatanje nove novčanice na krunskom području jer se ništa nije promenilo u prometu u ovim krajevima: i dalje se plaćalo krunama, po istim cenama kao do tada, a ni dužničko-poverilački odnosi nisu poremećeni. Jedina je promena, kako je pisao Milko Brezigar, što će se na državnim blagajnama primenjivati kurs 4:1 umesto 3,5:1. ${ }^{81}$ Time je vladi omogućen jedan reklamni motiv: da u proglasu kaže da se kruna unifikuje al pari, što je bio stari zahtev iz prečanskih krajeva. Ovim je vlada u poslednji čas otežala priče o smanjenju vrednosti krune i oslabila efekte protivničke propagande, pa je i opozicioni Slovenec primetio: „Zavladala je u novinstvu konfuznost i obezglavljenost", tako da sada hvale vladino rešenje oni koji su je doskora grdili. I zaista, protivnici su morali da se pomuče kako bi našli nove zamerke, pa su smislili dve slabašne: da se time onemogućava da kruna u budućnosti ojača u odnosu na dinar i da će do gubitka imovine ipak doći onda kada nova novčanica bude zamenjena dinarskom. ${ }^{82}$ Političke tenzije su smanjene.

Zamena je započeta 16. februara 1920, prvo u Srbiji i Crnoj Gori, a zatim drugde, i trebalo je da bude završena do 15. marta, ali je produžavana do 3. juna. Sitne krunske novčanice zamenjene su od 16. maja do 4. juna 1921, a u jesen iste godine zamenjene su krune $u$ delu Dalmacije koji je po Rapalskom ugovoru pripao Jugoslaviji.

Zanimljivo je da zvanično nije saopšteno koliko je kruna povučeno, već samo koliko je dinara za to utrošeno - 1.277 miliona, po Narodnoj ban$\mathrm{ci}^{83}$ - što odgovara sumi od 5,1 milijardi kruna. Razloge misterije ne znamo. R. Notel navodi da je zamenjeno 8 milijardi kruna, a da se za jednu milijardu misli da je falsifikovana i prošvercovana u zemlju. ${ }^{84}$

Primetimo da navedeni način zamene kruna nije promenio novčani opticaj, jer je svaka stara kruna zamenjena novom u krunsko-dinarskoj novčanici, tako da su zalaganja Nedeljkovića i Ninčića za smanjenje opticaja ostala neostvarena.

${ }^{80}$ Službene novine, 18. januar 1920.

${ }^{81}$ Slovenski narod, 17. januar 1920.

82 Slovenec, 24. i 20. januar 1920.

${ }^{83}$ Narodna banka 1884-1934, 143.

${ }^{84}$ R. Notel, International Credit and Finance, u: M. Kaser and E. Radice (eds), The Economic History of Eastern Europe, 1919-1975, Oxford, 1986, 176. 
Tokom 1922. krunsko-dinarske novčanice su zamenjene novom dinarskom novčanicom Narodne banke Kraljevine SHS, čime je okončan postupak valutne reforme: dinar je od 1. januara 1923. postao jedino sredstvo plaćanja u zemlji. Time je, u mirnoj atmosferi, okončano mučno pitanje monetarnog uređenja zemlje.

I pored svih protesta i naknadnih tumačenja, zamenom po kursu 4:1 vlasnici kruna u Kraljevini SHS prošli su odlično u poređenju s vlasnicima iz Austrije, što pokazuje obračun preko stabilnih deviza. Tako je za svoj novac imalac 1000 kruna u Beču tokom februara 1920. mogao dobiti samo 3,8 dolara, pošto je prosečan kurs ovog meseca bio 263 krune za jedan dolar. $^{85} \mathrm{~S}$ druge strane, tokom istog meseca za 1000 kruna u Jugoslaviji moglo se dobiti 8,8 dolara na Beogradskoj berzi, jer je kurs dolar/kruna bio 114,2:1. U Beogradu se, dakle, za isti iznos kruna moglo dobiti 2,3 puta više dolara nego u Beču.

Uzrok ove razlike lako je naći: to su mere zaštite vrednosti krune od austrougarske inflacije koje je Jugoslavija primenila tokom prethodnog perioda, uključujući i kurs 4:1. Naime, da nije bilo tih mera arbitraža bi dovela do jednakosti kursa krune u Beču i Beogradu na bečkom nivou, dok razlika u kursevima potvrđuje da je bilo ozbiljnih prepreka slobodnoj trgovini. Te prepreke su mere koje je jugoslovenska vlast zavela kako bi se zemlja odbranila od poplave kruna, od žigosanja i markiranja preko zabrane uvoza kruna i izvoza stabilnih deviza do kursa zamene. Tako je delimično izdvajanje SHS kruna iz krunskog sistema donelo, zajedno s domaćim kursom, relativno povoljan rezultat za vlasnike kruna.

\section{Posledice zamene}

Po svemu sudeći, zamena austrougarskih kruna nije izazvala negativne ekonomske i socijalne posledice, nasuprot onom što su kritičari prognozirali.

Po okončanju zamene došlo je čak do jačanja dinara: jedan francuski franak na Beogradskoj berzi prosečno je vredeo 3,1 dinara u martu, da bi pao na prosečnih 1,2 dinara u junu $1920 .{ }^{86}$ To veliko jačanje dinara svakako je izazvano rešenjem valutnog pitanja, odnosno uverenjem i domaće i strane publike da je valutna kriza u Jugoslaviji okončana i da je zemlja dobila stabilan novac. Oduševljeni Trgovinski glasnik „odao je priznanje“ ministrima koji su rešili valutno pitanje Ninčiću, Veljkoviću i Velizaru Jankoviću, ${ }^{87}$ koji je preuzeo ministarstvo finansija 19. februara, dok je zamena

\footnotetext{
${ }^{85} \mathrm{~J}$. van Walre de Bordes, $n$. d., 126-127.

${ }^{86}$ Narodna banka 1884-1934, 302.

${ }^{87}$ Trgovinski glasnik, 4. juli 1920.
} 
vršena. Time je nakratko kritičarima zamene oduzeta svaka argumentacija, a izgledalo je da će bivši vlasnici kruna (i dinara) biti lepo nagrađeni. Nastavak emisije novca za potrebe budžeta, međutim, uzrokovao je potom znatan berzanski pad dinara.

Unifikacija valuta nije dovela ni do „hiperinflacije“, kako tvrdi Kršev, ${ }^{88}$ a iz dva razloga: prvo, hiperinflacije uopšte nije bilo (velikoprodajne cene su 1922 . bile veće samo za $42 \%$ nego 1920) ${ }^{89}$ drugo, unifikacija uopšte nije donela porast novčanog opticaja, pa stoga ne bi mogla da skrivi hiperinflaciju čak i da je ova postojala, tako da je ova navodna „visoka cena“ unifikacije potpuno izmišljena.

Negativnih ekonomskih posledica nije bilo. Tih godina čak je postojala odlična poslovna konjunktura, s velikom investicionom aktivnošću, $u$ kojoj je izgrađen znatan deo industrije međuratne Jugoslavije. ${ }^{90}$ Kako je rekao jedan industrijalac: „Nastalo je doba neviđene konjunkture i prometa“. ${ }^{91}$ Polet je u prečanskim krajevima započet još 1919, a u Srbiji 1920. godine. ${ }^{92}$ Zagrebačke banke nastavile su sa brzim rastom kapitala. ${ }^{93} \mathrm{Da}$ je zamena kruna uništila tri četvrtine imovine u prečanskim krajevima, takve konjunkture svakako ne bi bilo. Ona je okončana prestankom emisionog finansiranja budžetskih deficita i politikom jakog dinara koju je vodio Milan Stojadinović u periodu 1924-1925. godine. ${ }^{94}$

Konačni nestanak krune, prvo sa novčanica i iz cenovnika tokom 1922, a zatim i zakonski, nije izazvao nikakve polemike, žalbe, trzavice. Zanimljivo je zato što je tek tada, sa nestankom krune, moglo doći do smanjenja imovine vlasnika kruna, sa svim užasnim posledicama, o kome je toliko govoreno dve-tri godine ranije. Dok je pojavom krunsko-dinarske novčanice početkom 1920. kruna zadržana bez ikakvih promena, ali praćena žestokim protestima, dotle je prilikom njenog nestanka vladao muk. Niko nije primetio da se nešto promenilo - iako je tek sada kurs 4:1 doneo promenu brojčanih odnosa.

\footnotetext{
${ }^{88}$ B. Kršev, Finansijska politika Jugoslavije 1918-1941, Novi Sad 2008, 74.

${ }^{89}$ Izračunato na osnovu Lj. Dukanac, Indeksi konjunkturnog razvoja Jugoslavije 1919-1941, Beograd 1946.

${ }^{90}$ V. Bajkić, Priroda i uzroci današnje ekonomske krize kod nas, Ekonomist, br. $3 / 1924$.

${ }^{91}$ Bankarstvo, br. 3/1926, 118.

${ }_{92}$ I. Belin, Naš novčani opticaj, Ekonomist, br. 11/1924, 954.

${ }^{93}$ Belin navodi da su sopstvena sredstva ovih banaka porasla sa 600 miliona kruna krajem 1919. na 1.500 miliona krajem 1920. - Uloga banaka u narodnoj privredi, Nova Evropa, br. 14/1920, 474.

${ }_{94}$ B. Mijatović, Ekonomska politika i konjunktura u Jugoslaviji 1919-1925, zbornik radova sa naučnog skupa Poreklo i ishodi kriza održanog 20. aprila 2010. u SANU (u štampi).
} 
Boško Mijatović

THE EXCHANGE OF AUSTRIAN CROWNS FOR DINARS IN 1920

\section{Summary}

Upon the formation of Yugoslavia it was necessary to withdraw several foreign currencies circulating in the country in order to achieve monetary sovereignty and stability. This issue was politically sensitive because the exchange of currencies meant (re)distribution of purchasing power to provinces and nations. The process of replacing Austrian crown notes with dinars started in February of 1920. The exchange rate was 4 crowns for 1 Serbian dinar, which was reasonable due to the higher purchasing power of the dinar against the crown, the prevailing market exchange rate, large dinar's metallic reserves compared to the crown and because of the need to compensate dinar's region for the expropriate exchange rate applied by the Austro-Hungarian government during the War. The currency exchange had positive effects. The results were more beneficial for those using crowns in Yugoslavia than in Austria or Hungary. There was a great economic conjuncture in the country. The exchange rate of the new Yugoslav Dinar immediately increased significantly, and the unification did not bring an influx of inferior Crowns from adjacent regions and thus Yugoslavia preserved its scarce capital. 